\title{
Multi-Business Firms, Knowledge Flows and Intra-Network Open Innovations
}

\author{
Manuel Villasalero ${ }^{1}$
}

Received: 15 October 2015 / Accepted: 28 October 2015 /

Published online: 6 November 2015

(C) The Author(s) 2015. This article is published with open access at Springerlink.com

\begin{abstract}
The increasing competition in the marketplace has led firms to change their innovation patterns to a more open system according to which they rely on networks to manage knowledge resources and innovate. The so-called open innovation paradigm has been developed by taking single-business firms and external networks as cornerstones of the standard model. However, in the case of multi-business firms, the role of internal networks has been neglected. Business units within multi-business corporations have the potential advantage of relying on both external partners and internal peers in order to support their product innovation process. The corporate network thus enables business units to provide knowledge (source knowledge from) to peers in their quest to bring new products onto the market. This study analyses the impact of four types of open innovation activities on business units' product innovation performance, which are classified according to the directionality (outside-in and inside-out) and locus (cross-business and across-boundaries) of the innovation flows. The results from a sample of 227 business units show that business units should look outside firm boundaries for inbound innovation and throughout business units for outbound innovation if they are to improve their innovation performance.
\end{abstract}

Keywords Knowledge networks · Diversification · Business unit · Innovation performance $\cdot$ Product innovation $\cdot$ Knowledge flows

\section{Introduction}

Creativity and knowledge are increasingly important if firms are to remain competitive in the global economy (Schiavone and Villasalero 2013; Villasalero et al. 2011), and

Manuel Villasalero

Manuel.Villasalero@uclm.es

1 Faculty of Law and Social Sciences, University of Castilla-La Mancha, Ronda de Toledo, s/n 13071, Ciudad Real, Spain 
this aspect is gradually leading firms to change their innovation patterns to a more open system, according to which they rely on external networks in order to manage knowledge resources and innovate (Chesbrough 2003, 2006). Rather than using exclusively internal research and development $(R \& D)$ to support innovation processes, and devoting internal R\&D outcomes exclusively to their own innovation efforts in accordance with the vertically integrated innovation paradigm, the open innovation paradigm postulates the use of both external knowledge from within to support innovation, and internal knowledge from outside to capitalize on innovations (Schroll and Mild 2011; Frankenberger et al. 2014). What is known as outbound innovation implies the selling and revealing of innovations and ideas outside the firm's boundaries, whereas what is known as inbound innovation entails acquiring and sourcing of innovations and ideas from outside the organizational limits (Dahlander and Gann 2010).

Existing studies on open innovation have assumed a model of the firm according to which decision-making, as regards innovation, is centralized and firm boundaries are well-defined, as in the case of single-business firms. However, multi-business firms deviate markedly from this model (Herzog and Leker 2010). On the one hand, strategic decision-making is divided between the corporate office and the business units in diversified firms, which may lead to a divergence of interests as regards inbound and outbound innovation activities and the differentiated impact of those decisions on corporate and business unit levels. On the other hand, a business unit's boundaries include the internal network, which is composed of sister business units and the corporate office, in addition to the widely-studied external network beyond the firm boundaries, which signifies the possibility of trade-offs between the internal and external networks.

Only two studies have dealt with open innovation in diversified firms (Cesaroni 2004; Lichtenthaler 2010), neither of which have adopted a business unit level perspective to address the issue of how business units engage in traditional (external) open innovation activities when they may also rely on internal network innovations. The objective of this study is therefore to shed light on the unexplored issue of business units' involvement in open innovation and its effect on business units' innovation performance, thereby analysing whether there are subtleties involved in being a multibusiness firm in the open innovation-innovation performance relationship. It is argued that business units are embedded in internal exchange networks which involve innovation-related knowledge inflows and outflows in similar manner as they are connected to external networks for inbound and outbound innovation. The common feature in internal (intra-network) and external exchanges is, therefore, that a knowledge flow takes place, whether it is a knowledge transfer within the organization's boundaries or an external knowledge transfer across the firm's limits. It is postulated that the locus in which the innovation-related knowledge transfer is carried out matters for business unit's innovation performance. This study specifically hypothesizes that external inbound innovation is more beneficial than internal inbound innovation, whereas external outbound innovation is less beneficial than internal outbound innovation. The results derived from a sample of 227 business units from top Spain-based diversified firms confirm the role that internal networks have played in business units' innovation efforts and support the fact that business units should look outside the firm's limits for inbound innovation and inside organization boundaries for outbound innovation if they are to strength innovation performance. 


\section{Multi-Business Firms as Internal Networks}

Multi-business firms can be regarded as internal markets in which exchanges among business units (divisions) occur in three key dimensions: capital flows, product flows and knowledge flows (Gupta and Govindarajan 2000; Liebeskind 2000). These same types of exchanges take place in the traditional external markets in which standalone firms engage in multiple transactions involving financial, physical and intangible resources (Williamson 1991; Chatterjee and Wernerfelt 1991). The portfolio of hierarchically organized business units in a diversified firm replaces an equivalent collection of independently acting firms in different external markets, such as the capital market (Duchin and Sosyura 2013), the labour market (Neffke and Henning 2013) or the technology market (Breschi et al. 2003). In other words, the economy, as a network of industries connected through decentralized external markets, is partially substituted by the multi-business firm as a network of business units connected through centralized internal markets (Ahern and Harford 2014).

The level to which multi-business firms' internal networks displace specialized firms' external exchanges varies from industry to industry (Santaló and Becerra 2006, 2008), and depends on one alternative being comparatively more efficient than another in each concrete setting (Maksimovic and Phillips 2002; Schoar 2002; Shackman 2007; Villalonga 2004), but it is evident that, overall, multi-business firms are currently a pervasive form of economic activity (Basu 2010; Fan and Lang 2000; Rondi and Vannoni 2005). One important determinant of internal networks being comparatively more efficient than external exchanges is, among others, precisely the efficiency with which product and factor markets conduct transactions externally (Chakrabarti et al. 2007; Khanna and Yafeh 2007). Bearing in mind that most product and capital markets work in an increasingly more correct manner in developed economies, the opportunities for a multi-business firm to beat those markets through internal arrangements in order to conduct capital and product flows are rather scarce (Shackman 2007). On the contrary, the markets for knowledge are still far from being perfect, even in developed countries with strong property rights regimes, thus providing an opportunity for multi-business firms to organize internal knowledge flows throughout business units more efficiently than in the external market for knowledge (Branstetter et al. 2006; Lichtenthaler and Ernst 2007).

The frictions of markets for knowledge, coupled with the increasing importance of knowledge assets, force our attention toward knowledge flows in multi-business firms. Corporate-level managers acknowledge that diversified firms' competitiveness revolves around the internal transfer of knowledge and the exploitation of knowledge relatedness within the internal network (Breschi et al. 2003; Tanriverdi and Venkatraman 2005). From a business level perspective, a concrete business unit plays a double role within the knowledge network, as both a provider of knowledge to the rest of the firm and a receiver of knowledge from the rest of the firm. Business units are thus involved in knowledge outflows and inflows within the diversified firm boundaries (Villasalero 2013, 2014a), and some of these knowledge flows pertain to innovation activities and impact on innovation outcomes at the business unit level (Tsai 2001). 


\section{Intra-Network Open Innovations}

The recognition of multi-business firms as internal networks, in which the business units are involved in knowledge outflows and knowledge inflows with sister business units and the corporate office, merits attention in the context of open innovation models since a single business unit has double the possibility of relying on the internal network (as is assumed in corporate diversification research) and/or the external network (as is advocated in the open innovation field) to support its innovation efforts.

The literature on open innovation is focused on the role that external networks play in innovation, either on the outbound innovation front whereby firms exploit their internal knowledge outside organizational boundaries or on the inbound innovation front whereby firms explore external knowledge inside organizational boundaries (Rass et al. 2013). In the former case, the firm engages in knowledge outflows to firms, previous employees or communities via selling and revealing innovations (e.g. outlicensing, spin-offs and open source communities) (Villasalero 2014b), whereas the latter case implies the firm being involved in knowledge inflows from firms, research institutions or customers by acquiring innovations and sourcing ideas (e.g. in-licensing, innovation contracts and innovation contests) (Dahlander and Gann 2010).

With the notable exceptions of Cesaroni (2004) and Lichtenthaler (2010), the studies dealing with open innovation have to date been based on a model of the firm corresponding to single-business firms, according to which it is relatively straightforward to delineate the organizational boundaries and consequently make a fairly clear distinction between the internal and external knowledge to be used inside and outside organizational limits. However, multi-business firms entail a different setting in which business units may use both internal and external networks in order to explore and exploit innovations, in addition to their own internal resources residing within their business units. For example, one business unit that is the owner of a patent may be interested in licensing it to a sister business unit rather than doing so to another firm, which is termed as intra-network outbound innovation in this study (as opposed to what could be termed as extra-network outbound innovation or simply outbound innovation). One business unit may similarly rely on a sister business unit's idea as to how serve a common customer with a new product rather than obtaining that information directly from lead users, which is termed as intra-network inbound innovation in this study (as opposed to inbound innovation or what could be termed as extra-network inbound innovation).

The common element when a business unit makes use of external or internal networks to support its innovation efforts is that a knowledge flow takes place, no matter what the directionality of that flow is (knowledge inflows in the case of inbound innovation; knowledge outflows in the case of outbound innovation) or what its receiver or source are (other parts of the corporation in the case of intra-network innovations; someone or something outside the corporation in the case of extranetwork innovations).

\section{Open Innovation and Innovation Performance}

As is suggested by Lichtenthaler (2010), in multi-business firms, inbound innovation is less problematic than outbound innovation because of the division of strategic decision- 
making between the corporate and business levels in these types of firms. Outbound innovation can hamper the long-term competitive position and the innovation outcomes of a business unit because it makes key technologies upon which that business unit depends available to competitors, while it may be simultaneously beneficial for the firm as a whole. For example, corporate officers may be interested in selling the future of some of their businesses in exchange for cash to build the firm's future in other businesses, a decision that will probably not be favoured by the general managers in charge of the harvested business units. In other words, some decisions regarding outbound innovation may be suboptimal from a business unit level perspective, even when the corporate office achieves an optimal balance from a firm level perspective. These potential adverse effects will of course occur in some business units and not in others, and a neutral overall effect can therefore be expected at the business unit level in contrast with the findings attained at the corporate level (Arora et al. 2001). We thus advance the following hypothesis:

\section{$H_{1}$ : A business unit's outbound innovation has no impact on the business unit's innovation performance.}

On the contrary, inbound innovation is not subject to so many pitfalls in the context of multi-business firms (Cesaroni 2004). The worst scenario for a business unit interested in some kind of inbound innovation is that of an opposition exercised by the corporate office on the grounds of competitive considerations or even because a second-choice-an internal alternative-is postulated (such as an inter-divisional exchange or an exchange between the corporate office and the focal business unit). However, as long as the inbound innovation is permitted there are no subtleties as regards being a multi-business firm that disrupt the general finding of favourable innovation outcomes associated with inbound innovation. The following hypothesis is thus proposed:

\section{$\mathrm{H}_{2}$ : A business unit's inbound innovation has a positive impact on the business unit's innovation performance.}

\section{Intra-Network Innovation and Innovation Performance}

Turning our attention toward intra-network innovation processes and their corresponding innovation performance, this study tests two hypotheses based on the premise that the predicted effects are symmetrical to those of their extra-network counterparts. From the provider business unit perspective, internal outbound innovation is far less problematic than external outbound innovation. The risk of putting business units' technologies in the hands of peers within the firm boundaries is less severe than that of transferring those technologies to (actual or potential) competitors across organizational limits (Breschi et al. 2003). Moreover, as far as the focal business unit's innovation performance is concerned, the internal transference of innovations to peers could trigger additional benefits for the source business unit in terms of the articulation and codification of the tacit knowledge involved in the exchange, which are rather more difficult to capitalize on in the case of external transference processes (Nonaka 1994; Nonaka 
and Takeuchi 1998). These benefits would accrue to the source business unit even in the case of the corporate office imposing mandatory internal exchanges under a strict policy of forced cross-business collaboration. The following hypothesis is therefore put forward:

\section{$H_{3}$ : A business unit's outbound innovation within the internal multi-business network has a positive impact on the business unit's innovation performance.}

There are several reasons why the effects of intra-network inbound innovation activities on innovation performance are predicted to run in the opposite direction to those corresponding to their external counterparts. First, many corporate offices do not resist the temptation of imposing some levels of forced collaboration among their business units, including technological exchanges which are somewhat unproductive and divert the resources that it is necessary to seek outside the firm's boundaries. Second, it is much more difficult to find the best technological solution or bright idea from a couple of business units than from hundreds of firms or millions of customers. In other words, the scope of inbound innovation within firm boundaries is generally narrow and forcibly stretched by corporate policies to the point of even having a detrimental effect on the receiver business unit's innovation performance. Again, these negative repercussions will only occur in some business units while not in others, thus leading to an overall neutral effect in a large number of cases. The following hypothesis is therefore advanced:

\section{$H_{4}: A$ business unit's inbound innovation within the internal multi-business network has no impact on the business unit's innovation performance.}

To recapitulate on the set of four hypotheses described above, this study postulates that there are subtleties involved in being a multi-business firm which suggest that business units should focus their inbound innovation efforts externally while focusing their outbound innovation actions internally.

\section{Methods}

The largest Spanish firms with either a dominant-, related- or unrelated-business strategy were selected for this study (Rumelt 1974), which resulted in a population of 518 business units belonging to 100 multi-business firms. Further details on the population are available in Villasalero (2013), including validity tests and the identity of the firms.

The variables were measured by using survey data for business units and secondary data for firms just prior to the financial crisis that hit the global economy in 2008. The field work began with a letter informing the corporate offices of our intention to mail questionnaires and the reasons behind this, including an organization chart that detailed the business units into which each firm was organized and the general managers in charge of each business unit. These organization charts were revised by the corporate offices and some amendments were returned to the researchers. The questionnaires were then mailed to the general managers with a cover-letter informing them that the 
research project had been presented to the corporate officers and making it clear that their responses would be analysed in the strictest confidence. After three mailing rounds, we obtained information for 227 divisions belonging to 76 firms. The response rate was therefore 76 per cent for firms and 43 per cent for divisions. Given the remarkable response rate, no response biases were detected between respondents and non-respondents.

\section{Innovation Performance}

The dependent variable is the innovation performance achieved by each business unit. Rather than an absolute measure, this study has adopted a relative measure in order to control for the objectives assigned to the business unit by the corporate office on the innovation front. This measure was based on an instrument developed by Gupta and Govindarajan (1986), which assesses the level to which a business unit is effective in attaining objectives weighted by the importance of those objectives for the corporate office. The computation of this measurement involves two related scales: a scale designed to disclose the business unit's balanced scorecard, and a scale used to assess the business unit's ability to do what is required in accordance with the balanced scorecard. The final measurement is a weighted index with which to address the business unit's effectiveness as regards performing its corporate-imposed role in the corporate business portfolio (Gupta and Govindarajan 1986). Only those items pertaining to product innovation outcomes were retained for the purposes of this study.

The content validity of innovation performance was analysed through the use of correlations between our measurement and two accounting measurements. Most Spanish firms do not disclose information for business units, but we detected 31 exceptions. The correlation between our innovation performance measure and the return on assets (ROA) were notable ( $n=31$ divisions; $r=0.255 ; p<0.001$ ), as were those between our division performance measurement and the return on equity (ROE) ( $n=31$ divisions; $r=0.233 ; p<0.001$ ). Although the correlations between accountingbased performance measures and innovative outcomes were not expected to be strong, the fact that they run in the same direction to a significant degree supported the validity of the latter. The convergent validity was strong since the inter-rater agreement rate was over $83 \%$ based on 10 questionnaires (administered to both corporate officers and general managers).

\section{Open Innovation}

The independent variables are outbound and inbound innovation both outside and inside organization boundaries. This signifies that four variables are of interest for this study, which are the traditional variables consisting of outbound innovation and inbound innovation along with the new internal variables dealing with intra-network outbound and intra-network inbound innovation.

The measurement of these variables is based on an instrument, the use of which implied that business units' general managers were asked to break down the percentage of activities performed by a business unit according to the beneficiaries of those activities. These were: self-consumption (own business unit); sister divisions and the corporate office (internal outflows); or non-affiliated partners, independent firms, spin- 
offs and non-pecuniary communities of users (external outflows). With this instrument, the measurement of outbound innovation is derived from the level to which a focal business unit is involved in internal outflows (intra-network outbound innovation) and external outflows (open outbound innovation). The instrument encompasses nine different activities, one of which refers to product innovation activities and processes as the focus of this study. Rather than directly using the resulting percentage, the final measure is weighted by the importance attached to product innovation activities and processes in the business unit's value chain.

The business units' general managers were also asked to symmetrically break down the percentage of activities in favour of the business units that were performed by the business unit itself (self-serving); sister divisions and the corporate office (internal inflows); or non-affiliated partners, independent firms, lead customers and non-pecuniary communities of users (external inflows). In parallel to the use of the aforementioned instrument, the measurement of inbound innovation was carried out by simply taking the percentages for each focal business unit when it is a receiver of either internal inflows (intra-network inbound innovation) or external inflows (open inbound innovation). As in the previous case, only the item pertaining to product innovation activities and processes (out of nine available items spanning different activities) was selected for the purposes of this study. The final measure was also weighted by the importance of product innovation activities and processes throughout the business unit's value chain.

A test for the validity of the inbound and outbound innovation measures was performed by checking the correlations of those measures with the business unit's size. As expected, larger business units have more resource independence than their smaller counterparts and they are therefore recurring to more self-consumption and self-serving and, consequently, less inbound innovation ( $n=227$ business units; $r=-0.110 ; p<0.10$ ) and outbound innovation ( $n=227$ business units; $r=-0.116 ; p<0.10$ ). The validity of the intra-network measures of inbound and outbound innovation was checked by correlating them with the firm's level of diversification. As expected, those business units from more diverse (less focused) multi-business firms are less involved in intranetwork exchanges in the form of inbound innovation $(n=227$ business units; $r=$ $-0.219 ; p<0.001)$ and outbound innovation $(n=227$ business units; $r=-0.156$; $p<0.05)$ within organizational boundaries.

\section{Control Variables}

Division heterogeneity was controlled by considering six variables. The structural variable consisting of business unit size was measured as the natural logarithm of the division's workforce (Keats and Hitt 1988). Two variables pertaining to the environment in which the business unit operates were introduced, which were industry membership and environmental uncertainty. Industry membership was operationalized by using three dummy variables to delineate four major groups in which the business units operate, these being water, energy and telecoms (private utilities); banking and insurance; construction and real estate; and manufacturing and technology (Dess et al. 1990). Environmental uncertainty (Cronbach's alpha $=0.835 ; n=20$ items) measures the general manager's skill as regards confronting the business unit's environment, and is 
made up of the degree to which the suppliers', competitors', financiers', regulators' and workers' actions are unpredictable (Buchko 1994).

Three strategic variables were considered, which were diversification strategy, strategic mission and prospector orientation. Diversification strategy was operationalized by using dummy variables to capture the dominant, related or unrelated diversification strategy adopted by the firm to which the business unit belongs (Rumelt 1974). Strategic mission (Cronbach's alpha $=0.567 ; n=2$ items) measures the role assigned by the corporate office to the business unit throughout the continuum between the extreme positions of harvesting (prioritizing short-term profitability over long-term market share) and building (prioritizing long-term market share over short-term profitability) (Gupta and Govindarajan 1984). Prospector orientation captures the business unit's strategy ranging from the defender profile to the prospector profile (Miles and Snow 1978), in accordance with the division manager's self-typing as regards the degree to which the division tends to change products and markets (Shortell and Zajac 1990).

\section{Results}

Multicollinearity is not an issue since no correlation is above 0.4 , with the exceptions of the correlation between prospector strategy and innovation performance and the correlation between internal inbound and outbound innovation, leaving aside the spurious correlations among dummy variables (Table 1).

The strong correlation between prospector strategy and innovation performance is in line with theoretically derived expectations (DeSarbo et al. 2005), and, in this respect, represents a further proof of the validity of the innovation performance measure at the business unit level used in this study. But the strong correlation does not imply a multicollinearity issue, as innovation performance is entered as the dependent variable in the regression models, whereas the prospector strategy is entered as an independent variable. On the other hand, the strong correlation between the intra-network measures of inbound and outbound innovation suggests that those business units that are active as providers of innovations within organizational boundaries are also active seekers of innovations from the internal knowledge network. This association would thus appear to be explained by a case of reciprocity in internal exchanges. Although there is a strong relationship between internal inbound innovation and internal outbound innovation, the former does not significantly correlate with innovation performance while the latter does which not only ensures the discriminant validity of both measures but also reflects the fact that they are measuring different dimensions of the internal innovation process (Venkatraman and Grant 1986). The potential multicollinearity issue was confronted by inspecting the variance inflation factors (VIF) in the different regression models estimated to test the hypotheses, and in no case was the VIF above 1.8 in any of the independent variables, a value that is well below the 4.0 threshold above which regression estimators become unstable (Cohen et al. 2003).

With regard to the remaining correlations, the control variables' environmental uncertainty, related diversification, build strategic mission and prospector orientation are all positively correlated with innovation performance, in contrast with unrelated diversification which is negatively correlated with it. Division size is negatively correlated with innovation performance, but the relationship is far from being 


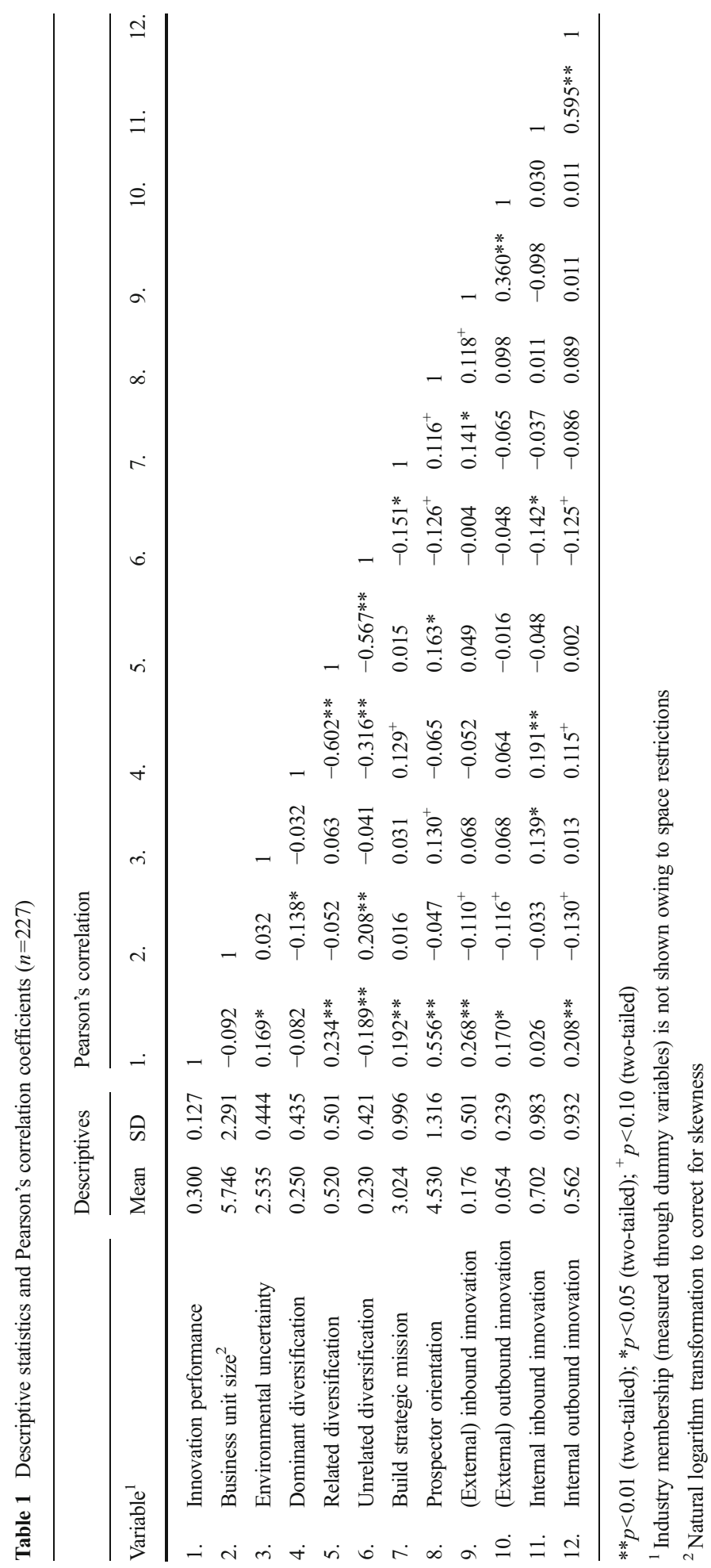


significant. The business units that compete in the banking and insurance industries have significantly better innovative outcomes, whereas those that compete in the construction and real estate industries exhibit the opposite pattern. In line with the relations hypothesized, external inbound innovation and internal outbound innovation correlate positively and significantly with innovation performance. The remaining principal variables of external outbound innovation and internal inbound innovation also exhibit positive correlations with innovation performance, but they are either less significant or non-significant, respectively.

The first set of hypotheses deals with a business unit's innovation across organizational boundaries, whereas the second set is concerned with innovation within organizational boundaries but across business unit limits. These hypotheses were contrasted by applying the linear regression analysis. Division size, environmental uncertainty, diversification strategy, build strategic mission and prospector orientation were used as control variables. Various models in which the control variables were entered first were estimated in a stepwise procedure (Table 2).

The dependent variable innovation performance is regressed only on the control variables in model 1. In this baseline model, related diversification, the building of a strategic mission and prospector orientation are significant predictors of innovation performance, whereas environmental uncertainty almost attains significance and division size proves to be non-significant. The goodness of fit of Model 1 is notable, with an adjusted $R^{2}$ that far exceeds the recommended threshold of 0.20 for baseline models.

Models 2 and 3 add the main variables dealing with external and internal innovation, respectively. These models lead to an improvement in the explanatory capacity of the baseline model, since the resulting increments in $R^{2}$ are highly significant in both cases. Consistent with the first and second hypotheses, Model 2 shows that inbound innovation has beneficial effects on a business unit's innovation performance, in contrast with the negligible effects that outbound innovation has on it. Model 3 also shows conformity with the fourth hypothesis that contends that intra-network outbound innovation is beneficial for a business unit's innovation performance. The remaining third hypothesis anticipated that intra-network inbound innovation is indifferent as regards a business unit's innovation performance, but the findings from Model 3 detect a marginally significant detrimental effect. This unexpected and marginally significant finding from partial Model 3 has yet to be confirmed in the full Model 4.

Model 4 corresponds to the case in which innovation performance is regressed on all the variables. The findings from the previous partial models remain the same in the full model with two minor changes. With regard to the control variables, environmental uncertainty reaches statistical marginal significance as in Model 3. With regard to the main variables, internal inbound innovation fails to reach the minimum threshold of statistical significance, thus losing the marginal statistical significance achieved in the partial Model 3. The full model implies a highly significant increase in the explanatory capacity as regards the previous partial models and almost reaches an adjusted $R^{2}$ of 0.40 , a value slightly beyond that usually obtained in behavioural research (Rosenthal et al. 2000).

Further robustness checks were carried out by entering industry membership through the use of dummy variables. This expanded model's goodness of fit is worse than that of Model 4, while it increases multicollinearity substantially as measured using VIF. The findings remain the same with the exception of related diversification, 
Table 2 OLS linear regression (dependent variable: innovation performance)

\begin{tabular}{|c|c|c|c|c|c|}
\hline \multirow[b]{2}{*}{ Effect } & \multirow[b]{2}{*}{ Variable } & \multicolumn{4}{|c|}{$\begin{array}{l}\text { Unstandardized coefficients with standard errors in } \\
\text { parentheses }\end{array}$} \\
\hline & & $\begin{array}{l}\text { Model } 1 \\
\text { controls }\end{array}$ & $\begin{array}{l}\text { Model } 2 \\
\text { external }\end{array}$ & $\begin{array}{l}\text { Model } 3 \\
\text { internal }\end{array}$ & $\begin{array}{l}\text { Model } 4 \\
\text { total }\end{array}$ \\
\hline \multirow[t]{7}{*}{ Control } & Constant & $\begin{array}{l}-0.038 \\
(0.056)\end{array}$ & $\begin{array}{l}-0.033 \\
(0.054)\end{array}$ & $\begin{array}{l}-0.061 \\
(0.055)\end{array}$ & $\begin{array}{l}-0.055 \\
(0.054)\end{array}$ \\
\hline & Business unit size & $\begin{array}{l}-0.003 \\
(0.003)\end{array}$ & $\begin{array}{l}-0.002 \\
(0.003)\end{array}$ & $\begin{array}{l}-0.002 \\
(0.003)\end{array}$ & $\begin{array}{l}-0.001 \\
(0.003)\end{array}$ \\
\hline & Environmental uncertainty & $\begin{array}{l}0.027 \\
(0.017)\end{array}$ & $\begin{array}{l}0.023 \\
(0.017)\end{array}$ & $\begin{array}{l}0.032^{+} \\
(0.017)\end{array}$ & $\begin{array}{l}0.027^{+} \\
(0.016)\end{array}$ \\
\hline & Dominant diversification $^{1}$ & $\begin{array}{l}0.006 \\
(0.022)\end{array}$ & $\begin{array}{l}0.010 \\
(0.022)\end{array}$ & $\begin{array}{l}0.004 \\
(0.022)\end{array}$ & $\begin{array}{l}0.006 \\
(0.022)\end{array}$ \\
\hline & Related diversification $^{1}$ & $\begin{array}{l}0.039^{*} \\
(0.019)\end{array}$ & $\begin{array}{l}0.041^{*} \\
(0.019)\end{array}$ & $\begin{array}{l}0.037^{*} \\
(0.019)\end{array}$ & $\begin{array}{l}0.038^{*} \\
(0.018)\end{array}$ \\
\hline & Build strategic mission & $\begin{array}{l}0.016^{*} \\
(0.008)\end{array}$ & $\begin{array}{l}0.014^{+} \\
(0.008)\end{array}$ & $\begin{array}{l}0.019^{*} \\
(0.007)\end{array}$ & $\begin{array}{l}0.017^{*} \\
(0.007)\end{array}$ \\
\hline & Prospector orientation & $\begin{array}{l}0.049 * * \\
(0.006)\end{array}$ & $\begin{array}{l}0.047 * * \\
(0.006)\end{array}$ & $\begin{array}{l}0.046 * * \\
(0.006)\end{array}$ & $\begin{array}{l}0.045 * * \\
(0.006)\end{array}$ \\
\hline \multirow[t]{4}{*}{ Main } & (External) inbound innovation & & $\begin{array}{l}0.040^{*} \\
(0.016)\end{array}$ & & $\begin{array}{l}0.035^{*} \\
(0.016)\end{array}$ \\
\hline & (External) outbound innovation & & $\begin{array}{l}0.034 \\
(0.033)\end{array}$ & & $\begin{array}{l}0.041 \\
(0.033)\end{array}$ \\
\hline & Internal inbound innovation & & & $\begin{array}{l}-0.018^{+} \\
(0.009)\end{array}$ & $\begin{array}{l}-0.015 \\
(0.009)\end{array}$ \\
\hline & Internal outbound innovation & & & $\begin{array}{l}0.034 * * \\
(0.010)\end{array}$ & $\begin{array}{l}0.033 * * \\
(0.010)\end{array}$ \\
\hline \multirow[t]{5}{*}{ Goodness of fit } & $R^{2}$ adjusted & 0.339 & 0.368 & 0.372 & 0.398 \\
\hline & $R^{2}$ & 0.359 & 0.394 & 0.398 & 0.429 \\
\hline & $\Delta R^{2}$ & & $0.034 * *$ & $0.039 * *$ & $0.036^{* *}$ \\
\hline & $F$ & $17.561 * *$ & $15.092 * *$ & $15.360^{* *}$ & $13.838^{* *}$ \\
\hline & $N$ & 227 & 227 & 227 & 227 \\
\hline
\end{tabular}

${ }^{* *} p<0.01, * p<0.05,+p<0.10$

${ }^{1}$ Corporate diversification strategy; the effects must be interpreted in contrast with the omitted unrelated diversification category

which loses statistical significance. A detailed inspection of the data reveals that industry membership and diversification strategy are in fact multicollinear, as detected in previous studies (Montgomery 1985). In our sample, dominant-business firms tend to focus on water, energy and telecoms and manufacturing and technology industries; related diversifiers concentrate on banking and insurance industries; and unrelated diversifiers focus on construction and real estate industries. Following the theoretical position that a diversification strategy precedes industry membership (Montgomery and Hariharan 1991) and the fact that our empirical results show the statistical superiority of the former over the latter, this study retains Model 4 as the final model, in which diversification strategy is included and industry membership is excluded. It is worth 
recalling that the remaining findings remain the same in any specification, including those findings concerning the four hypotheses tested.

\section{Discussion and Conclusion}

These results support the view held in this study that open innovation does not suit multi-business firms in the same way in which it suits single-business firms. Like single-business firms, the business units from multi-business firms may rely on the external network of other firms, research institutions, lead customers and community users to support and leverage their innovative efforts, but they also have the additional possibilities provided by the internal network of peer business units, corporate research centres and the corporate office (Fig. 1).

The findings indicate that business units should look outside the multi-business firm boundaries to carry out inbound innovation and inside the multi-business firm boundaries to carry out outbound innovation. When using the Dahlander and Gann (2010) framework, the business unit's involvement in open innovation is beneficial inasmuch as it is focused on the external network to acquire innovations and source ideas and on the internal network to sell and reveal innovations and ideas. These findings have both research and managerial implications.

\section{Managerial Implications}

With regard to the managerial implications, it is worth noting that the level of analysis adopted in this study is that of the business unit level, and the findings cannot therefore be generalized to the firm level. In fact, the results indicate that the business unit's innovation performance is improved as a consequence of intranetwork outbound innovation, but is not improved with intra-network inbound innovation. In other words, the cross-business transfer of innovation-related knowledge is beneficial for the provider business unit but is indifferent for the receiver business unit. The combination of beneficial and neutral effects on innovation performance at the business unit level implies that intra-network open innovation is, overall, beneficial for the multi-business firm, but it does not preclude situations

\begin{tabular}{|c|c|c|c|}
\hline & External & $\begin{array}{l}\text { ACROSS BOUNDARY } \\
\text { KNOWLEDGE INFLOWS } \\
(+)\end{array}$ & $\begin{array}{c}\text { ACROSS BOUNDARY } \\
\text { KNOWLEDGE OUTFLOWS } \\
(?)\end{array}$ \\
\hline minovate & Internal & $\begin{array}{c}\text { CROSS-BUSINESS } \\
\text { KNOWLEDGE INFLOWS } \\
\text { (?) }\end{array}$ & $\begin{array}{l}\text { CROSS-BUSINESS } \\
\text { KNOWLEDGE OUTFLOWS } \\
(+)\end{array}$ \\
\hline
\end{tabular}

Fig. 1 Open innovation and knowledge flows in multi-business firms 
in which a concrete business unit's innovation performance is damaged for the wellbeing of the whole multi-business firm (Villasalero 2013).

A similar reasoning is applicable to the exchanges of business units with their external networks. Inbound innovation across organizational boundaries is beneficial for a business unit's innovation performance, in contrast to outbound innovation which has neutral effects on it. Overall, these findings obtained at the business unit level suggest that open innovation is thus favourable for multi-business firms. The fact that outbound innovation is not beneficial for provider business units does not imply that the selling and revealing of innovations cannot be beneficial for multi-business firms as a whole, even in cases in which the interest of concrete business units may be damaged (Lichtenthaler 2010).

\section{Research Implications}

Besides considering the external and internal network distinction, it is interesting to discuss these findings in the light of the role played by business units as providers or receivers of innovation-related knowledge. Being a provider of innovations and ideas is beneficial if the transfer is for internal recipients (e.g. peer business units), while it proves to be neutral if it is for external recipients (e.g. licensee firms). This asymmetry in the manner through which an internal and external transfer impacts on the provider's innovation performance is theoretically compelling. Possible explanations revolve around a more advantageous learning curve within the boundaries of the firm rather than outside, which is consistent with knowledge management theories (Nonaka 1994) and knowledge-based views of the firm (Grant 1996). According to Nonaka (1994), it is possible that the provider business unit benefits more from the articulation of tacit knowledge (externalization) in the process of internal transfer than in the process of external transfer simply because tacit knowledge is less frequently transferred across organizational boundaries than explicit knowledge. Following the view advanced by Grant (1997) of firms as superior integrative mechanisms of knowledge pieces to the market mechanism, the internal integration of knowledge may render more learning advancements for the provider business unit when it is carried out within rather than across organizational boundaries.

The findings are symmetrical in the situation in which the business unit is the receiver of innovation-related knowledge; external knowledge inflows are beneficial, whereas internal knowledge inflows remain neutral. This difference is also consistent with knowledge management theories that stress requisite variety as a driver of the learning process and accelerator of the knowledge spiral. The requisite variety refers to the level to which the members of the organization have "the fastest access to the broadest variety of necessary information, going through the fewest steps" (Nonaka and Takeuchi 1998, p. 231). The requisite variety associated with inbound innovation is usually greater outside than inside the firm because the diversity of information is broader and the speed with which it can be obtained is frequently higher. On the contrary, the intra-network locus of inbound innovation is probably of too restricted a scope to ensure sufficient variety for the learning process to be accelerated for the receiver business unit's benefit. 


\section{Limitations and Future Studies}

The major contribution of this study is the extension of the open innovation paradigm (Van de Vrande et al. 2010) in the setting of multi-business firms by using a within-firm operationalization of open innovation as suggested recently by West and Bogers (2014). The adoption of a business unit level perspective reveals substitution effects between the business unit's internal and external networks with regard to innovationrelated knowledge inflows and outflows. The outcome variable for these findings is a business unit's innovation performance. Future studies may investigate the impact of internal and external innovation activities on alternative outcome performance measures, such as financial or business performance (Faems et al. 2010). Besides extending the conceptualization of the dependent variable, the scope of the independent variables could also be broadened by including not only strictly innovation-related knowledge flows, but also knowledge flows pertaining to market, logistic, customer service or brand knowledge, taking into account the fact that innovation ideas may originate in almost every activity of the firm's value chain (Bogers and West 2012).

This study also adds to the recent literature that is expanding the research on open innovation to a variety of industries, including service industries (Chesbrough 2011a, b, c; Fasnacht 2009; Mention 2011; van de Vrande et al. 2009; Spithoven et al. 2013) and low-tech settings (Chesbrough and Crowther 2006; Chiaroni et al. 2010; Grimpe and Sofka 2009; Spithoven et al. 2010). Future studies may check the sensibility of these findings in different types of industries.

Acknowledgments The author would like to thank the editor and anonymous reviewers for their constructive and helpful comments on the paper. The author is grateful for the cooperation of the firms without which this study would not have been possible. This research was supported by the American Consortium on European Union Studies (ACES, grant number GWPTA 27290/16/ECNS20983N), the Regional Government of Castilla-La Mancha (grant number POll-2014-007-A) and the European Union under the European Regional Development Fund (operational programme number 2007ES161PO007). This article is dedicated to the memory of María Dolores Jiménez Castro, whose untimely death has left a huge void in the lives of many of us at the University of Castilla-La Mancha and has deprived me of her unfailing support, insightful advice and wonderful company in the Vice Chancellor's Office for Economics and Planning, in which she served passionately and dedicatedly as Chief of Staff during the last 10 years amid the admiration and affection of us all.

Open Access This article is distributed under the terms of the Creative Commons Attribution 4.0 International License (http://creativecommons.org/licenses/by/4.0/), which permits unrestricted use, distribution, and reproduction in any medium, provided you give appropriate credit to the original author(s) and the source, provide a link to the Creative Commons license, and indicate if changes were made.

\section{References}

Ahern, K. R., \& Harford, J. (2014). The importance of industry links in merger waves. The Journal Of Finance, 69(2), 527-576. doi:10.1111/Jofi.12122.

Arora, A., Fosfuri, A., \& Gambardella, A. (2001). Markets for technology: the economics of innovation and corporate strategy. Cambridge, Ma.: MIT Press.

Basu, N. (2010). Trends in corporate diversification. Financial Markets And Portfolio Management, 24(1), 87-102. doi:10.1007/S11408-009-0123-0. 
Bogers, M., \& West, J. (2012). Managing distributed innovation: strategic utilization of open and user innovation. Creativity And Innovation Management, 21(1), 61-75. doi:10.1111/J.1467-8691.2011. 00622.X.

Branstetter, L. G., Fisman, R., \& Foley, C. F. (2006). Do stronger intellectual property rights increase international technology transfer? Empirical evidence from US firm-level panel data. Quarterly Journal Of Economics, 121(1), 321-349. doi:10.1093/Qje/121.1.321.

Breschi, S., Lissoni, F., \& Malerba, F. (2003). Knowledge-relatedness in firm technological diversification. Research Policy, 32(1), 69-87.

Buchko, A. A. (1994). Conceptualization and measurement of environmental uncertainty: an assessment of the miles and snow perceived environmental uncertainty scale. Academy Of Management Journal, 37(2), $410-425$.

Cesaroni, F. (2004). Technological outsourcing and product diversification: do markets for technology affect firms' strategies? Research Policy, 33(10), 1547-1564. doi:10.1016/J.Respol.2004.08.003.

Chakrabarti, A., Singh, K., \& Mahmood, I. (2007). Diversification and performance: evidence from East Asian firms. Strategic Management Journal, 28(2), 101-120. doi:10.1002/Smj.572.

Chatterjee, S., \& Wernerfelt, B. (1991). The link between resources and type of diversification: theory and evidence. Strategic Management Journal, 12(1), 33-48. doi:10.1002/Smj.4250120104.

Chesbrough, H. W. (2003). Open innovation: the new imperative for creating and profiting from technology. Boston, MA.: Harvard Business School Press.

Chesbrough, H. W. (2006). Open business models: how to thrive in the new innovation landscape. Boston, MA.: Harvard Business School Press.

Chesbrough, H. W. (2011a). Bringing open innovation to services. MIT Sloan Management Review, 52(2), 8590.

Chesbrough, H. W. (2011b). The case for open services innovation: the commodity trap. California Management Review, 53(3), 5-20.

Chesbrough, H. W. (2011c). Open services innovation: rethinking your business to grow and compete in a new era. San Francisco: Jossey-Bass.

Chesbrough, H. W., \& Crowther, A. K. (2006). Beyond high tech: early adopters of open innovation in other industries. R\&D Management, 36(3), 229-236. doi:10.1111/J.1467-9310.2006.00428.X.

Chiaroni, D., Chiesa, V., \& Frattini, F. (2010). Unravelling the process from closed to open innovation: evidence from mature, asset-intensive industries. R\&D Management, 40(3), 222-245. doi:10.1111/J. 1467-9310.2010.00589.X.

Cohen, J., Cohen, P., West, S. G., \& Aiken, L. S. (2003). Applied multiple regression/correlation analysis for the behavioral sciences. London: Lawrence Erlbaum Associates.

Dahlander, L., \& Gann, D. M. (2010). How open is innovation? Research Policy, 39(6), 699-709. doi:10. 1016/J.Respol.2010.01.013.

Desarbo, W. S., Di Benedetto, C. A., Song, M., \& Sinha, I. (2005). Revisiting the miles and snow strategic framework: uncovering interrelationships between strategic types, capabilities, environmental uncertainty, and firm performance. Strategic Management Journal, 26(1), 47-74.

Dess, G. G., Ireland, R. D., \& Hitt, M. A. (1990). Industry effects and strategic management research. Journal Of Management, 16(1), 7-27.

Duchin, R., \& Sosyura, D. (2013). Divisional managers and internal capital markets. Journal Of Finance, 68(2), 387-429. doi:10.1111/Jofi.12003.

Faems, D., De Visser, M., Andries, P., \& Van Looy, B. (2010). Technology alliance portfolios and financial performance: value-enhancing and cost-increasing effects of open innovation. Journal Of Product Innovation Management, 27(6), 785-796. doi:10.1111/J.1540-5885.2010.00752.X.

Fan, J. P. H., \& Lang, L. H. P. (2000). The measurement of relatedness: an application to corporate diversification. The Journal Of Business, 73(4), 629-660.

Fasnacht, D. (2009). Open innovation in the financial services: growing through openness, flexibility and customer integration. Berlin: Springer.

Frankenberger, K., Weiblen, T., \& Gassmann, O. (2014). The antecedents of open business models: an exploratory study of incumbent firms. $R \& D$ Management, 44(2), 173-188. doi:10.1111/Radm.12040.

Grant, R. M. (1996). Toward a knowledge-based theory of the firm. Strategic Management Journal, 17(Winter Special Issue), 109-122.

Grant, R. M. (1997). The knowledge-based view of the firm: implications for management practice. Long Range Planning: International Journal Of Strategic Management, 30(3), 450-454.

Grimpe, C., \& Sofka, W. (2009). Search patterns and absorptive capacity: low- and high-technology sectors in European countries. Research Policy, 38(3), 495-506. doi:10.1016/J.Respol.2008.10.006. 
Gupta, A. K., \& Govindarajan, V. (1984). Business unit strategy, managerial characteristics, and business unit effectiveness at strategy implementation. Academy Of Management Journal, 27(1), 25-41.

Gupta, A. K., \& Govindarajan, V. (1986). Resource sharing among SBUs: strategic antecedents and administrative implications. Academy Of Management Journal, 29(4), 695-714. doi:10.2307/255940.

Gupta, A. K., \& Govindarajan, V. (2000). Knowledge flows within multinational corporations. Strategic Management Journal, 21(4), 473-496. doi:10.1002/(Sici)1097-0266(200004)21:4<473::Aid-Smj84>3.0. Co;2-I.

Herzog, P., \& Leker, J. (2010). Open and closed innovation-different innovation cultures for different strategies. International Journal Of Technology Management, 52(3/4), 322-343. doi:10.1504/Ijtm.2010. 035979.

Keats, B. W., \& Hitt, M. A. (1988). A causal model of linkages among environmental dimensions, macro organizational characteristics, and performance. Academy Of Management Journal, 31(3), 570-598.

Khanna, T., \& Yafeh, Y. (2007). Business groups in emerging markets: paragons or parasites? Journal Of Economic Literature, 45(2), 331-372. doi:10.1257/Jel.45.2.331.

Lichtenthaler, U. (2010). Organizing for external technology exploitation in diversified firms. Journal Of Business Research, 63(11), 1245-1253. doi:10.1016/J.Jbusres.2009.11.005.

Lichtenthaler, U., \& Ernst, H. (2007). Developing reputation to overcome the imperfections in the markets for knowledge. Research Policy, 36(1), 37-55. doi:10.1016/J.Respol.2006.08.005.

Liebeskind, J. P. (2000). Internal capital markets: benefits, costs, and organizational arrangements. Organization Science, 11(1), 58-76.

Maksimovic, V., \& Phillips, G. (2002). Do conglomerate firms allocate resources inefficiently across industries? Theory and evidence. Journal Of Finance, 57(2), 721-767. doi:10.1111/1540-6261.00440.

Mention, A.-L. (2011). Co-operation and Co-opetition as open innovation practices in the service sector: which influence on innovation novelty? Technovation, 31(1), 44-53. doi:10.1016/J.Technovation.2010. 08.002 .

Miles, R. E., \& Snow, C. C. (1978). Organizational strategy, structure, and process. New York: McGraw-Hill.

Montgomery, C. A. (1985). Product-market diversification and market power. Academy Of Management Journal, 28(4), 789-798.

Montgomery, C. A., \& Hariharan, S. (1991). Diversified expansion by large established firms. Journal Of Economic Behavior \& Organization, 15(1), 71-89. doi:10.1016/0167-2681(91)90005-I.

Neffke, F., \& Henning, M. (2013). Skill relatedness and firm diversification. Strategic Management Journal, 34(3), 297-316. doi:10.1002/Smj.2014.

Nonaka, I. (1994). A dynamic theory of organizational knowledge creation. Organization Science, 5(1), 14 37.

Nonaka, I., \& Takeuchi, H. (1998). A theory of the firm's knowledge-creation dynamics. In A. D. Chandler, P. Hagstrom, \& Ö. Sölvell (Eds.), The dynamic firm: the role of technology, strategy, organization, and regions (pp. 214-241). Oxford: Oxford University Press.

Rass, M., Dumbach, M., Danzinger, F., Bullinger, A. C., \& Moeslein, K. M. (2013). Open innovation and firm performance: the mediating role of social capital. Creativity And Innovation Management, 22(2), 177194. doi:10.1111/Caim.12028.

Rondi, L., \& Vannoni, D. (2005). Are Eu leading firms returning to core business? Evidence on refocusing and relatedness in a period of market integration. Review Of Industrial Organization, 27(2), 125-145. doi:10. 1007/S11151-005-8322-Y.

Rosenthal, R., Rosnow, R. L., \& Rubin, D. B. (2000). Contrasts and effect sizes in behavioral research: a correlational approach. Cambridge: Cambridge University Press.

Rumelt, R. P. (1974). Strategy, structure, and economic performance. Cambridge, MA: Harvard Business School.

Santaló, J., \& Becerra, M. (2006). The dominance of diversified versus specialized firms across industries. Journal Of Business Research, 59(3), 335-340. doi:10.1016/J.Jbusres.2005.09.006.

Santaló, J., \& Becerra, M. (2008). Competition from specialized firms and the diversification-performance linkage. Journal Of Finance, 63(2), 851-883. doi:10.1111/J.1540-6261.2008.01333.X.

Schiavone, F., \& Villasalero, M. (2013). Creativity, organizational knowledge, and the power of dreams. Journal Of The Knowledge Economy, 4(3), 279-292. doi:10.1007/S13132-013-0159-2.

Schoar, A. (2002). Effects of corporate diversification on productivity. Journal Of Finance, 57(6), 2379-2403. doi:10.1111/1540-6261.00500.

Schroll, A., \& Mild, A. (2011). Open innovation modes and the role of internal R\&D. European Journal Of Innovation Management, 14(4), 475-495. doi:10.1108/14601061111174925.

Shackman, J. D. (2007). Corporate diversification, vertical integration, and internal capital markets: a crosscountry study. Management International Review, 47(4), 479-504. 
Shortell, S. M., \& Zajac, E. J. (1990). Perceptual and archival measures of Miles and Snow's strategic types: a comprehensive assessment of reliability and validity. Academy Of Management Journal, 33(4), 817-832.

Spithoven, A., Clarysse, B., \& Knockaert, M. (2010). Building absorptive capacity to organise inbound open innovation in traditional industries. Technovation, 30(2), 130-141. doi:10.1016/J.Technovation.2009.08. 004.

Spithoven, A., Vanhaverbeke, W., \& Roijakkers, N. (2013). Open innovation practices in smes and large enterprises. Small Business Economics, 41(3), 537-562. doi:10.1007/S11187-012-9453-9.

Tanriverdi, H., \& Venkatraman, N. (2005). Knowledge relatedness and the performance of multibusiness firms. Strategic Management Journal, 26(2), 97-119.

Tsai, W. (2001). Knowledge Transfer In Intraorganizational Networks: Effects Of Network Position And Absorptive Capacity On Business Unit Innovation And Performance. Academy Of Management Journal, 44(5), 996-1004.

Van De Vrande, V., De Jong, J. P. J., Vanhaverbeke, W., \& De Rochemont, M. (2009). Open innovation in SMEs: trends, motives and management challenges. Technovation, 29(6/7), 423-437. doi:10.1016/J. Technovation.2008.10.001.

Van De Vrande, V., Vanhaverbeke, W., \& Gassmann, O. (2010). Broadening the scope of open innovation: past research, current state and future directions. International Journal Of Technology Management, 52(3/4), 221-235. doi:10.1504/Ijtm.2010.035974.

Venkatraman, N., \& Grant, J. H. (1986). Construct measurement in organizational strategy research: a critique and proposal. Academy Of Management Review, 11(1), 71-87. doi:10.2307/258332.

Villalonga, B. (2004). Diversification discount or premium? New evidence from the business information tracking series. The Journal Of Finance, 59(2), 479-506. doi:10.1111/J.1540-6261.2004.00640.X.

Villasalero, M. (2013). Signaling, spillover and learning effects of knowledge flows on division performance within related diversified firms. Journal Of Knowledge Management, 17(6), 928-942. doi:10.1108/Jkm03-2013-0101.

Villasalero, M. (2014a). Intra-network knowledge roles and division performance in multi-business firms. Journal Of Knowledge Management, 18(6), 1165-1183. doi:10.1108/Jkm-03-2014-0104.

Villasalero, M. (2014b). University knowledge, open innovation and technological capital in spanish science parks: research revealing or technology selling? Journal Of Intellectual Capital, 15(4), 1469-1930. doi: 10.1108/Jic-07-2014-0083.

Villasalero, M., Pinar, J. M., \& García, F. P. (2011). Technological innovation and dynamic capabilities in the Spanish wind energy business. Journal Of Euromarketing, 20(3-4), 18-38. doi:10.9768/0020.34.03.

West, J., \& Bogers, M. (2014). Leveraging external sources of innovation: a review of research on open innovation. Journal Of Product Innovation Management, 31(4), 814-831. doi:10.1111/Jpim.12125.

Williamson, O. E. (1991). Strategizing, economizing, and economic organization. Strategic Management Journal, 12(S2), 75-94. doi:10.1002/Smj.4250121007. 